(C) 2021, The Authors. Published by Elsevier Inc. and Fass Inc. on behalf of the American Dairy Science Association ${ }^{\circledR}$. This is an open access article under the CC BY-NC-ND license (http://creativecommons.org/licenses/by-nc-nd/4.0/).

\title{
Prevalence, risk factors, and effects on fertility of cytological endometritis at the time of insemination in Norwegian Red cows
}

\author{
S. Diaz-Lundahl, ${ }^{1 *}$ (๑ R. T. Garmo, ${ }^{1,2 *} \odot$ P. Gillund, ${ }^{3}$ T. B. Klem, ${ }^{4} \odot$ A. Waldmann, ${ }^{5} \odot$ and A. K. Krogenæs ${ }^{1} \dagger \odot$ \\ ${ }^{1}$ Faculty of Veterinary Medicine, Department of Production Animal Clinical Sciences, Norwegian University of Life Sciences, PO Box 369 Sentrum, \\ 0102 Oslo, Norway \\ ${ }^{2}$ TINE SA, PO Box 58, 1430 Ås, Norway \\ ${ }^{3}$ GENO Breeding and AI Association, Storhamargata 44, 2317 Hamar, Norway \\ ${ }^{4}$ Department of Animal Health and Food Safety, Norwegian Veterinary Institute, PO Box 750 Sentrum, 0106 Oslo, Norway \\ ${ }^{5}$ Estonian University of Life Sciences, Institute of Veterinary Medicine and Animal Sciences, Kreutzwaldi 62, 51006 Tartu, Estonia
}

\begin{abstract}
The present study aimed to assess the occurrence of cytological endometritis (CYTO), a nonsymptomatic inflammation of the endometrium, at first artificial insemination (AI) postpartum in Norwegian Red cows. Further, risk factors for CYTO manifestation and its effect on reproductive success and late embryo loss were evaluated. In total 1,648 cows located in 116 herds were included in the study. On mainly spontaneous estrus, endometrial cytology samples were collected using a cytotape technique, and a total of 300 representative epithelial cells and polymorphonuclear neutrophils $(\mathrm{PMN})$ were counted at $400 \times$ magnification. Vaginal mucus obtained by Metricheck (Simcro) and body condition score were recorded. Milk samples for progesterone analysis were collected at AI and $21 \mathrm{~d}$ later. Pregnancy was diagnosed by rectal palpation or analysis of pregnancy-associated glycoproteins. Based on the constructions of a receiver operator characteristics curve, the cut-off level for PMN defined as CYTO was set to $3.0 \%$, representing the level at which the PMN occurrence affected pregnancy outcome, with the highest summation of sensitivity $(32.4 \%)$ and specificity $(74.9 \%)$. Three logistic models with herd included as random factor were constructed. The outcome for the first model was the likelihood for CYTO based on the endometrial samples, in the second model pregnancy to first AI, and in the third model embryo loss. The proportion of CYTO was $28.0 \%(461 / 1,648)$. The average interval in days to first AI was $71.7 \mathrm{~d}$ (standard error \pm 0.7 ) and the overall pregnancy incidence to first AI was $59.8 \%(866 / 1,449)$. The likelihood for CYTO at first AI was associated with AI personnel, calving to first AI
\end{abstract}

Received July 3, 2020.

Accepted December 27, 2020.

*These authors contributed equally to this work.

†Corresponding author: anette.krogenaes@nmbu.no interval, vaginal mucus characteristics, amount of red blood cells in sample, season, and barn type. Pregnancy to first AI was lower in CYTO-positive cows (odds ratio $=1.51$, confidence interval $=1.17-1.94$ ). Other factors affecting pregnancy to first AI were AI personnel, test day milk yield, barn type, and obstetrical conditions or fertility treatments before first AI. The proportion of late embryo loss and abortion was 8.6\% (82/948) and $2.8 \%$ (24/866), respectively. Late embryo loss was associated with treatment against fertility disorders before first AI, but not associated with CYTO. Overall, our results suggest that even if Norwegian Red cows show a fairly high prevalence of CYTO in the endometrium at first AI, it does not seem to have a major effect on the reproductive performance. The Norwegian Red breeding program has emphasized fertility and health for decades, and a genetically advantageous uterine immunology might be one of the preserved mechanisms. Key words: Norwegian Red, embryo loss, cytotape, cytological endometritis, polymorphonuclear neutrophils

\section{INTRODUCTION}

Embryo loss, defined as loss of conceptus during the first $42 \mathrm{~d}$ of pregnancy (Zavy and Geisert, 1994), is one of the major contributing factors affecting reproductive efficiency in dairy cows (Diskin and Morris, 2008). Embryo survival is negatively affected by suboptimal uterine environment (Hill and Gilbert, 2008). Hence, postpartum uterine disease has a great impact on reproductive performance in the dairy industry, causing large economic losses (Sheldon and Dobson, 2004). As a result, recent years has witnessed an increase in studies investigating the prevalence and effect of subclinical endometritis in dairy cows (Kasimanickam et al., 2004; Madoz et al., 2013; Wagener et al., 2017).

Subclinical endometritis is defined by 3 aspects: (1) the presence of PMN on the endometrial surface or lu- 
men, (2) a reduction in reproductive performance, and (3) the absence of clinical symptoms of endometritis (Kasimanickam et al., 2004; Sheldon and Owens, 2017). The diagnosis is usually based on cytology samples collected from the endometrial surface or lumen, where cytobrush or uterine lavage are the most common collection techniques (Pascottini et al., 2016; Sheldon and Owens, 2017; Wagener et al., 2017). Cytological endometritis (CYTO) refers to these cytological findings alone (Dubuc et al., 2010a; Pascottini et al., 2016).

It is challenging to compare studies on the prevalence of subclinical endometritis or CYTO because they are based on dissimilar sample time points relative to parturition, as well as different cut-off levels to define the condition (Pascottini et al., 2015; Wagener et al., 2017; Arias et al., 2018). While most published studies on CYTO or subclinical endometritis are based on sampling 3 to 5 wk or 5 to 7 wk after calving (Arias et al., 2018), Pascottini et al. (2016, 2017a) performed sampling at the time of AI, with the argument that this is the most critical point for uterine health status. Further, sampling at the time of AI allows for greater standardization regarding what cut-off value of PMN to use for the diagnosis of CYTO, as well as a more standardized collection procedure (Pascottini et al., 2017a). To prevent unnecessary penetration of the cervix, cytology samples were collected with a piece of tape (cytotape) attached to the sanitary sheath covering the insemination gun (Pascottini et al., 2015, 2017a,b). A consecutive study showed that this collection method did not affect the pregnancy rate (Pascottini et al., 2017a), although there was a risk of the insemination procedure itself introducing a PMN response in the endometrium (Pascottini et al., 2017b). Earlier identified factors for the increased risk of CYTO at first AI in multiparous cows include parity, DIM, and season of the year (Pascottini et al., 2017b).

It has been reported in several studies that CYTO has a negative effect on pregnancy outcome in dairy cattle (Kasimanickam et al., 2004; Gilbert et al., 2005; Dubuc et al., 2010a; Valdmann et al., 2018). Among the affected parameters were pregnancy rate (Kasimanickam et al., 2004; Gilbert et al., 2005; Dubuc et al., 2010a), days open (Kasimanickam et al., 2004; Gilbert et al., 2005; Valdmann et al., 2018), postpartum anestrus, and AI per conception (Gilbert et al., 2005). Similar negative effects on pregnancy outcome have also been identified when CYTO was diagnosed at AI (Pascottini et al., 2017a). In contrast, a small number of studies have also reported no significant effect of CYTO on reproductive performance in dairy cattle reared under less intensive systems, including Holstein cattle reared in a pasture-based, extensive dairy farming system in
Argentina (Plöntzke et al., 2010), and in small- and medium-sized herds of mainly Simmental in Austria (Prunner et al., 2014).

Norwegian Red has been the main breed of dairy cattle in Norway since 1935, and since the 1970s breeding programs have emphasized fertility and health, such that female fertility has been included in the total merit index in Norway since 1972 (Andersen-Ranberg et al., 2005). The population average interval from calving to first AI (CFAI) is $81.8 \mathrm{~d}$, and treatments against reproductive disorders are currently low, with treatments against metritis and endometritis equal to 1.3/100 cowyears in 2018 (TINE Rådgiving, 2019). A pregnancy incidence of $62.9 \%$ and a calving rate of $56.3 \%$ has been reported in Norwegian Red (Garmo et al., 2008), and the $56 \mathrm{~d}$ nonreturn rate was $72.4 \%$ in 2018 (Geno SA, 2016). The prevalence and effect of CYTO have not been investigated in this high fertility breed. Such knowledge would be valuable to understand the basis of the successful reproductive capacities of this breed, and if the success is due to, or rather in spite of a low occurrence of this condition. Our hypothesis was that because of the high fertility in Norwegian Red, CYTO is not very prevalent, as neither metritis nor endometritis are highly reported issues in this breed.

The present study aimed to assess the occurrence of CYTO, as defined by presence of PMN in the endometrium at first AI postpartum in Norwegian Red cows and to establish associated risk factors. Additional aims were (1) to investigate how pregnancy to first AI is affected by CYTO and by other already known risk factors and (2) to investigate the risk for late embryo loss and abortion with regard to PMN status at first AI.

\section{MATERIALS AND METHODS}

A prospective cohort field trial was conducted between September 2017 and March 2019. The study unit was Norwegian Red cows presented for first AI after parturition $(\mathrm{n}=1,648)$. The sample size was based on a difference in pregnancy to first AI of $10 \%$ between CYTO-positive and -negative animals, and the desired power and confidence interval (90\% and 95\%, respectively), and the true prevalence was expected to be 10\%. In total 116 herds in the counties of Hedmark (n $=52)$ and Trøndelag $(\mathrm{n}=64)$, with a range from 1 to 123 cows, were included in the study. The herds were selected based on the farmers' willingness to participate in the study. The animals were housed in 35 tiestall herds $(17.5 \%)$ and 87 freestall herds $(82.5 \%)$ of which $66(69.1 \%)$ had an automated milking system and 21 a traditional milking parlor system $(13.4 \%)$. The ethical approval for the present study was given by the Nor- 
wegian Food Safety Authority with approval number 17/152686-1. A cytological sample was collected from the endometrium in connection with first $\mathrm{AI}$ in 1,738 cows. Of these, 90 samples were excluded due to poor quality, resulting in the study being based on 1,648 endometrial samples. The cows were selected for AI mainly on spontaneous estrus, detected by mucus, estrus behavior, electronic activity monitors, or a combination of these. There was no voluntary waiting period, but a general recommendation from the Norwegian Red breeding organization (Geno SA) of at least $42 \mathrm{~d}$ from CFAI.

\section{Data from the Norwegian Dairy Herd Recording System}

All herds used in the study were part of the Norwegian Dairy Herd Recording System (NDHRS), which routinely records data on parity; parturition and AI date; pregnancy controls; culling data; disease occurrence; calf sex; dystocia; milk yield (MY); concentrate allocation (CA); milk fat, protein, and lactose content; natural logarithm of somatic cell count (LnSCC); and urea. All feed and milk data were measured and analyzed monthly and reported to NDHRS.

\section{Disease Treatment and Culling}

Registrations of disease treatments were retrieved from NDHRS for the period from $30 \mathrm{~d}$ before parturition until first $\mathrm{AI}$ in subsequent lactation. All diagnoses and treatments registered in NDHRS are performed and reported by veterinarians according to predefined health codes (Animalia, 2020). Calving-related conditions and diseases were diagnosed in 241 of the 1,648 cows included in the study. There were 48 cases of obstetrical conditions: dystocia, 9; prolonged pregnancy, 3 ; uterine prolapse, 1; uterus torsion, 1; retained placenta, 21; early metritis, 12; and others, 1. In total, 52 cases of fertility disorders were reported before first AI: anestrus, 16; ovarian cysts, 8; silent heat, 22; endometritis, 2; and estrus synchronization, 4. Other conditions with treatment registered were mastitis, 59; ketosis, indigestion, or both, 32; lameness, bone, and claw disorders, 9; and others, 41.

In total, 327 of the included cows were culled during the study period: 68 pregnant, 156 nonpregnant, and 103 with uncertain pregnancy status. Thirteen of these cows were culled 6 to $29 \mathrm{~d}$ after first AI and were not included in statistical analysis with pregnancy as outcome. The reasons for culling were abortion, 21; low MY, 49; mastitis or high SCC or poor udder confirmation, 75; poor fertility, 86; bone and confirmation, 20; and others, 76 .

\section{Al Personnel}

Eleven AI technicians and 3 veterinarians employed at GENO SA performed the sampling from the endometrium at first AI. The AI personnel were selected based on interest, experience, and competence, and before sampling, they participated in a one-day practical course. The course included a tutorial of body condition scoring and evaluations of the quality of their endometrial cytology samples. Five persons, both AI technicians and veterinarians, who in total performed only $7.5 \%(\mathrm{n}=124)$ of the AI and collected $\leq 46$ endometrial cytology samples each, were counted as one group in the statistical analyses, due to small numbers of AI ranging from 7 to 46 . The distribution of AI and endometrial samples between the other AI personnel was $22.5 \%(\mathrm{n}=370), 19.7 \%(\mathrm{n}=324), 15.5 \%(\mathrm{n}=$ $255), 8.8 \%(\mathrm{n}=145), 6.9 \%(\mathrm{n}=114), 6.9 \%(\mathrm{n}=113)$, $4.9 \%(\mathrm{n}=80), 4.5 \%(\mathrm{n}=74)$, and $3.0 \%(\mathrm{n}=49)$.

\section{BCS, Mucus Evaluation, and Endometrial Sampling on the Farm}

Body condition was scored by the AI personnel at first AI on a scale from 1 (very thin) to 5 (obese), in increments of 0.25 (Edmonson et al., 1989), modified and adjusted for Norwegian Red according to Gillund et al. (1999).

A Metricheck device (Metricheck, Simcro) was used to investigate and score the appearance of the vaginal mucus. Samples of mucus were collected and evaluated from 1,442 of the cows. The instrument was advanced to the cervix to collect mucus and withdrawn. The AI personnel assessed the content in comparison to pictures of vaginal mucus characteristics and gave a score from 0 to 3: score $0=$ clear or translucent mucus; score $1=$ mucus containing flecks of white or off-white pus; score $2=$ discharge containing $\leq 50 \%$ white or off-white mucopurulent material; score $3=$ discharge containing $\geq 50 \%$ purulent material, usually white or sanguineous (Williams et al., 2005).

A cytotape device was mounted and used to collect cytology samples from the endometrium, according to the technique developed by Pascottini et al. (2015). Briefly, paper tape was glued to the sanitary sheaths (IMV technologies Split Universal sheaths 007494) covering the insemination gun. A protective disposal plastic tube (Continental plastic, Sheath protector tubes 262-728-4800) was mounted over the sampling device. Following the cleaning of the vulva and perineum, the protective tube was passed into the uterus. The endometrial samples were collected by penetrating the protective tube, rolling the tape against the endometrium, releasing the semen, withdrawing the tape into the 
protective tube, and rolling the tape onto a microscope glass slide.

\section{Microscopic Evaluations and PMN Assessment}

The microscopic evaluation of the slides was performed by 3 veterinarians. A subset of 40 cytology slides were randomly chosen from the first 475 samples to calculate the interobserver reliability. Randomization was made using Sergeant, ESG, 2018, Epitools Epidemiological Calculators, Ausvet (available at http: //epitools.ausvet.com.au). Calculations were made using Stata (Stata SE/15.1, Stata Corp.). Kendall's $\mathrm{W}$ was 0.72 , which was assessed as high (Martin and Bateson, 2007). Calibration was performed by using example pictures and support from of a professional cytologist. The evaluation distribution between the 3 observers was $55.2 \%(\mathrm{n}=909), 31.4 \%(\mathrm{n}=518)$, and $13.4 \%(\mathrm{n}=221)$.

The slides were fixed and stained with Kruuse Dip Quick Stain (Jorvet, J0322A1, A2, A3, Jorgensen Laboratories) and examined under the $100 \times$ magnification in a light microscope. The amount of red blood cells $(\mathbf{R B C})$ was scored from 0 to $3: 0=$ none, $1=$ low, $2=$ moderate, $3=$ high, as previously described by Pascottini et al. (2015). The slides were assigned a quality score based on proportion of nonfragmented cells; $<50 \%, 50-75 \%,>75 \%$ (Pascottini et al., 2015). At $400 \times$ magnification, a total of 300 representative epithelial cells and PMN were counted in several fields and the proportion of PMN calculated.

\section{Estrus Confirmation and Pregnancy Detection}

Milk samples were collected by hand for progesterone analysis at the time of AI and 21 d post-AI. A Broad Spectrum Microtab tablet was added (D\&F Control Systems Inc.), and the samples were stored frozen at $-18^{\circ} \mathrm{C}$ before laboratory analysis. Milk progesterone was measured by enzyme immunoassay (Waldmann, 1993), which was modified by a second antibody coating technique. The specificity of the monoclonal antibody was described previously (Waldmann, 1999). For this method, the interassay coefficient of variation was 9.2 and $5.3 \%$, at milk progesterone concentrations of 1.48 and $19.66 \mathrm{ng} / \mathrm{mL}$, respectively, whereas the intraassay coefficient of variation was less than $10 \%$. The threshold for progesterone content in estrus was $\leq 3.0 \mathrm{ng} /$ $\mathrm{mL}$, while $>3.0 \mathrm{ng} / \mathrm{mL}$ indicated AI during diestrus. A progesterone content of $\leq 3.0 \mathrm{ng} / \mathrm{mL} 21 \mathrm{~d}$ after first AI was evaluated as return to estrus. Pregnancy to first AI was confirmed by rectal palpation by the AI personnel or by milk samples analyzed for pregnancyassociated glycoproteins (PAG) at $42 \mathrm{~d}$ after first AI. The PAG concentration was analyzed using an Idexx Milk Pregnancy Test (99-41209, Idexx Laboratories). A corrected optical density value of $>0.250$ was used as a cut-off to confirm pregnancy, whereas $<0.1$ indicated nonpregnancy. Results between 0.10 and 0.25 were recorded as re-check or uncertain. Cows presented for a subsequent AI within 18 to $42 \mathrm{~d}$, and a new calf born later than $290 \mathrm{~d}$ after first AI were assessed not to be pregnant after first AI.

\section{Late Embryonic Loss}

Late embryonic loss was defined as having happened in cows with progesterone levels $>3.0 \mathrm{ng} / \mathrm{mL} 21 \mathrm{~d}$ after the first AI, who were not pregnant on rectal palpation or PAG analysis $\leq 42 \mathrm{~d}$ after the first AI, or cows that were presented for a new $\mathrm{AI} \geq 42 \mathrm{~d}$ after first $\mathrm{AI}$, and with no recording on pregnancy status. Cows with $>3$ $\mathrm{ng} / \mathrm{mL}$ at $\mathrm{AI}$ were excluded from the material in the late embryonic loss model.

\section{Missing Observations}

Due to some missing observations, there are variations in cow numbers for milk samples, data retrieved in the field, and from NDHRS. There were missing milk samples for progesterone analysis both at first AI (n $=160)$ and at $\mathrm{d} 21(\mathrm{n}=201)$, but 1,287 cows were registered with progesterone data both at first AI and 21 d later.

\section{Statistical Analysis}

All statistical analyses were performed in Stata (Stata SE/15.1, Stata Corp.). Pearson's chi-squared test was used to test the univariate relationship between the different outcome variables and explanatory variables. Three logistic models were built: model 1 with CYTO based on endometrial samples, with no $=0$, yes $=1$, as the outcome. Model 2 with pregnancy $\geq 42 \mathrm{~d}$ after first AI, with yes $=0$, no $=1$, as the outcome. Model 3 with embryo loss, with yes $=0$ or no $=1$, as the outcome. To select the best cut-off point for the definition of CYTO in the logistic model with pregnancy as outcome, we constructed receiver operating characteristic (ROC) curves (Dohoo et al., 2009). The highest summation of sensitivity on $32.4 \%$ and corresponding specificity value on $74.9 \%$ was detected at the $3.0 \%$ level, Figure 1 . The positive and negative predictive values was $46.6 \%$ and $62.2 \%$, respectively, and the area under the curve was 


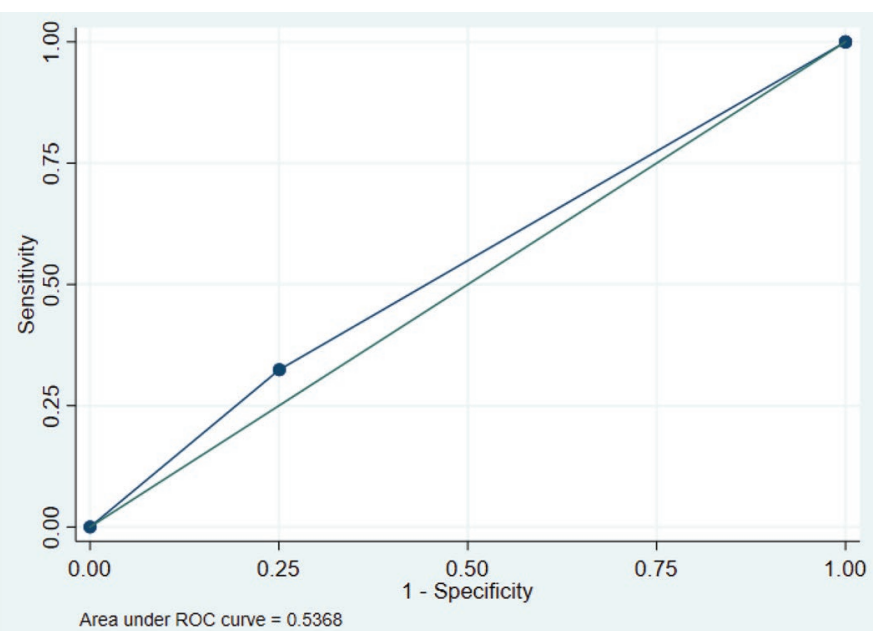

Figure 1. Receiver operating characteristics (ROC) curve with sensitivity of $32.4 \%$, specificity of $74.9 \%$, and area under the curve equal to 0.54 for cytological endometritis using cut-off at $3.0 \%$ polymorphonuclear cells in endometrial samples collected at first AI postpartum in Norwegian Red, $\mathrm{n}=1,449$.

0.54. In the logistic models with CYTO (model 1) and embryo loss (model 3) as outcomes, CYTO equal to $3.0 \%$ PMN was also used as the cut-off level.

Associations between the outcomes in the 3 models and the explanatory variables were tested separately using the random effects logistic model, $x$ tlogit, in Stata $\mathrm{SE} / 15.1$ with herd included as the random effect in the models. The following explanatory variables were tested univariately: parity (first, $>1$ ), CFAI, test day MY, test day CA, urea, and the LnSCC closest to first AI, herd size, barn type (automated milking system, milk parlor, tied), season (December-February, MarchMay, June-August, September-November), BCS at AI ( $\leq 2.75$ thin, $3.0-3.75$ optimal, $\geq 4.0$ fat), vaginal mucus $($ clear $=$ score 0 and opaque $=$ score 1 or 2 combined $)$, $\mathrm{RBC}$ occurrence in endometrial samples $(0=$ none, 1 $=$ low, $2=$ moderate, $3=$ high), calf size, as reported to NDHRS by the farmer based on experience (small, medium, large, twins), dystocia (none, some, large), obstetrical condition or fertility treatment before first AI, and finally milk fat, protein, and lactose \% at test day closest to first AI. In addition, the occurrence of PMN as a continuous variable or CYTO defined by a $3.0 \%$ level $($ no $=0$, yes $=1)$ was added as an explanatory variable in model 2 and model 3.

In all 3 models, explanatory variables with $P \leq 0.20$ when assessed separately were included in an extended multivariable model with herd included as random effects in the respective models. Co-linearity was assessed between explanatory variables by calculation of the Pearson correlation coefficient (Dohoo et al., 2009). Except for a correlation between CA and MY of 0.7 , no co-linearity between explanatory variables was detected, and MY was selected to be included in a multivariable model due to biological relevance. The backward elimination procedure was applied for explanatory variables with $P>0.05$ in the multivariable model, eliminating the variable with the highest $P$-value, re-running the model for each elimination of an explanatory variable. None of the interaction terms tested between the explanatory variables in the final models were associated with (1) CYTO in endometrial sample at first AI, (2) pregnancy to first AI, or (3) the occurrence of ED, and hence not included in either of the final models. The herd level residuals in the logistics models were reasonably normal. Only explanatory variables with $P \leq 0.05$ were retained in the final models. Number of cows with endometrial samples, BCS, milk yield, concentrate allocation, mucus evaluation, milk content samples, progesterone samples, and pregnancy diagnosis are presented in Appendix Table A1.

\section{RESULTS}

\section{Descriptive Statistics: Herd Level}

In the present study, the average herd size was 39 cows with a range from 13 to 110 cows. The average 305-d ECM production was 8,402.8 $\mathrm{kg} \pm 83.3$, whereas the average milk fat and protein content was $4.31 \% \pm$ 0.03 and $3.45 \% \pm 0.01$, respectively. There were 736 first and $912>1$ parity cows included in the study.

\section{Descriptive Statistics: Cow Level}

The overall pregnancy incidence to first AI was $59.8 \%$ $(866 / 1,449)$, and the corresponding values were $62.5 \%$ $(412 / 659)$ and $57.5 \%(454 / 790)$ for first and $>1$ parity, respectively.

The overall average CFAI was $71.7 \mathrm{~d} \pm 0.7$, and the corresponding values were $70.1 \mathrm{~d} \pm 1.0$ and $72.9 \mathrm{~d} \pm$ 1.0 for first and $>1$ parity, respectively. The proportion of double AI as a new AI recorded 1 to $4 \mathrm{~d}$ after first AI was 3.4\% (56/1,648).

Average MY closest to test day was $31.6 \mathrm{~kg} \pm 0.2$ (n $=1,602)$, whereas the average $\mathrm{CA}$ was $11.2 \mathrm{~kg} \pm 0.1$ $(\mathrm{n}=1,600)$. Average milk fat-, protein-, and lactose content at test day closest to the first AI was $4.08 \% \pm$ $0.02,3.27 \% \pm 0.01,4.71 \% \pm 0.01$, respectively, whereas the average test day $\mathrm{LnSCC}$ and urea was $3.89 \pm 0.03$ and $4.67 \mathrm{mmol} \pm 0.03$, respectively $(\mathrm{n}=1,586)$.

The distribution of AI $(\mathrm{n}=1,648)$ by season was $32.5 \%(\mathrm{n}=535)$ from December to February, $28.0 \%$ $(\mathrm{n}=461)$ from March to May, 22.9\% ( $\mathrm{n}=377)$ from June to August, and 16.7\% ( $\mathrm{n}=275)$ from September to November. 
The distribution of calf size $(\mathrm{n}=1,600)$ was $13.9 \%$ small $(\mathrm{n}=223), 69.9 \%$ medium $(\mathrm{n}=1,118)$, and $16.2 \%$ large $(\mathrm{n}=259)$. Twins were recorded in 1.7\% (28/1639) of the births, whereas dystocia was reported by the farmer in 148 cows (44 major and 104 minor).

The distribution of BCS $(\mathrm{n}=1,637)$ was divided into 3 groups: $13.2 \%(\mathrm{n}=216)$ with a $\mathrm{BCS} \leq 2.75,75.7 \%$ $(\mathrm{n}=1,240)$ with a BCS between 3.0 and 3.75 , and $11.1 \%(\mathrm{n}=181)$ with a $\mathrm{BCS} \geq 4.0$. Fourteen cows were recorded with a BCS between 2.0 and 2.25. Vaginal mucus was assessed in 1,442 cows. In $93.1 \%(\mathrm{n}=1,343)$ of the animals, the mucus was given score of 0 , whereas $6.2 \%(\mathrm{n}=89)$ had score of 1 , and $0.7 \%(\mathrm{n}=10)$ had a score of 2 . No sample was characterized with score 3 . There was no difference in pregnancy to first AI with $60.4 \%(717 / 1,188)$ and $62.3 \%(48 / 77)$ for cows with clear and opaque mucus, respectively. For the 10 cows with opaque or mucopurulent mucus, 2 were pregnant, 4 nonpregnant, 1 had uncertain pregnancy status, and 3 cows were inseminated during the luteal phase.

\section{CYTO and Descriptive Associations}

The distribution of PMN at first AI $(n=1,648)$ is presented in Table 1. The CYTO was present in $28.0 \%$ $(461 / 1,648)$ of the endometrial samples. Successful pregnancy, following the first AI, was recorded in $53.4 \%$ $(217 / 406)$ and $62.2 \%(649 / 1,043)$ of cows positive and negative for CYTO, respectively, $P<0.01$. The proportion of CYTO-positive samples was $26.7 \%(357 / 1,343)$ and $45.5 \%$ (45/99) for cows with clear and opaque mucus, respectively, $P<0.01$.

The distribution of RBC in the endometrial samples $(\mathrm{n}=1,648)$ was $57.8 \%(\mathrm{n}=953)$ without, $22.6 \%$ (n $=372)$ with low, $10.5 \%(\mathrm{n}=173)$ with moderate, and $9.1 \%(\mathrm{n}=150)$ with a high amount of RBC. Pregnancy following first AI was $59.8 \%(500 / 836)$ and $59.4 \%$ (364/613) for endometrial samples classified with or without RBC, respectively. Red blood cells were detected in $52.0 \%(239 / 460)$ and $38.4 \%(456 / 1,188)$ of the CYTO-positive and CYTO-negative samples, respectively, $P<0.01$.

\section{Insemination During the Luteal Phase}

Progesterone concentration at AI was $\leq 3.0 \mathrm{ng} / \mathrm{mL}$ in $96.1 \%(1,430 / 1,488)$ of the cows. The AI in diestrus was detected by a progesterone concentration of $>3.0$ $\mathrm{ng} / \mathrm{mL}$ in $3.9 \%(\mathrm{n}=58)$ of the cows, and these were excluded from the model with pregnancy as outcome. Among these cows, $32.8 \%(19 / 58)$ were CYTO positive. Fifteen cows with progesterone concentrations between 0.1 and $1.0 \mathrm{ng} / \mathrm{mL}$ at first AI were presented for a new AI $21 \mathrm{~d}$ later with progesterone concentrations between 7.8 and $27.9 \mathrm{ng} / \mathrm{mL}$. In $40.0 \%(6 / 15)$ of these cows, CYTO was observed in the endometrial sample at AI. Thirteen of these cows were presented for a new AI later in lactation or registered as nonpregnant by pregnancy control.

\section{Embryo and Fetal Loss}

The proportion of late embryo loss was $8.6 \%$ (82/948) and was restricted to 49 herds, with 1 to 7 embryo losses in each herd.

Fetal loss was recorded in 24 cows that was pregnant $42 \mathrm{~d}$ after first $\mathrm{AI}$ and presented for a new AI later, such that abortion percentage was $2.8 \%(24 / 866)$. The CYTO was observed in $29.3 \%(24 / 82)$ and $12.5 \%$ $(3 / 24)$ of the endometrial samples in cows with late embryo loss or fetal loss, respectively, and there was no difference in the chi-squared test, $P=0.25$.

\section{Model 1: Associations Between the Likelihood for CYTO in Endometrial Samples at First Al and Explanatory Variables}

The univariable analyses on relationships between the CYTO in the endometrial samples at first AI and explanatory variables are presented in Table 2. The following variables were associated with CYTO: AI personnel, CFAI, BCS, vaginal mucus condition, RBC in sample, barn type, and season.

In the multivariable model presented in Table 3, the likelihood of CYTO in the endometrium at first AI was associated with following predictors: AI personnel, CFAI, vaginal mucus condition, $\mathrm{RBC}$ in sample, season, and barn type. The likelihood of CYTO decreased from an odds ratio of 0.99 to 0.86 by increasing the interval for first AI by $21 \mathrm{~d}$, also meaning that the likelihood

Table 1. The occurrence of PMN counting 300 cells in endometrial samples from Norwegian Red cows at first AI $(\mathrm{n}=1,648)$ and pregnancy to first AI $(\mathrm{n}=1,449)$

\begin{tabular}{lrrrr}
\hline PMN \% & \multicolumn{1}{c}{ n } & \multicolumn{1}{c}{$\begin{array}{c}\text { Cumulative } \\
\%\end{array}$} & $\begin{array}{c}\text { Pregnancy } \% \\
\text { (no./total) }\end{array}$ \\
\hline No PMN & 686 & 41.6 & 41.6 & $62.5(383 / 613)$ \\
$\leq 0.9$ & 259 & 15.7 & 57.3 & $57.7(128 / 222)$ \\
$1.0-2.9$ & 242 & 14.7 & 72.0 & $66.3(138 / 208)$ \\
$3.0-4.9$ & 116 & 7.0 & 79.1 & $57.3(59 / 103)$ \\
$5.0-9.9$ & 130 & 7.9 & 87.0 & $56.1(64 / 114)$ \\
$10.0-19.9$ & 96 & 5.8 & 92.8 & $53.0(44 / 83)$ \\
$20.0-49.9$ & 86 & 5.2 & 98.0 & $47.4(36 / 76)$ \\
$\geq 50.0$ & 33 & 2.0 & 100.0 & $46.4(14 / 30)$ \\
Total & 1,648 & & & 1,449 \\
\hline
\end{tabular}


Table 2. Univariable analyses describing associations between the occurrence of cytological endometritis $(0=$ no, baseline, $1=$ yes $)$ and explanatory variables in 1,648 Norwegian Red cows from 116 herds (herd is included as a random effect)

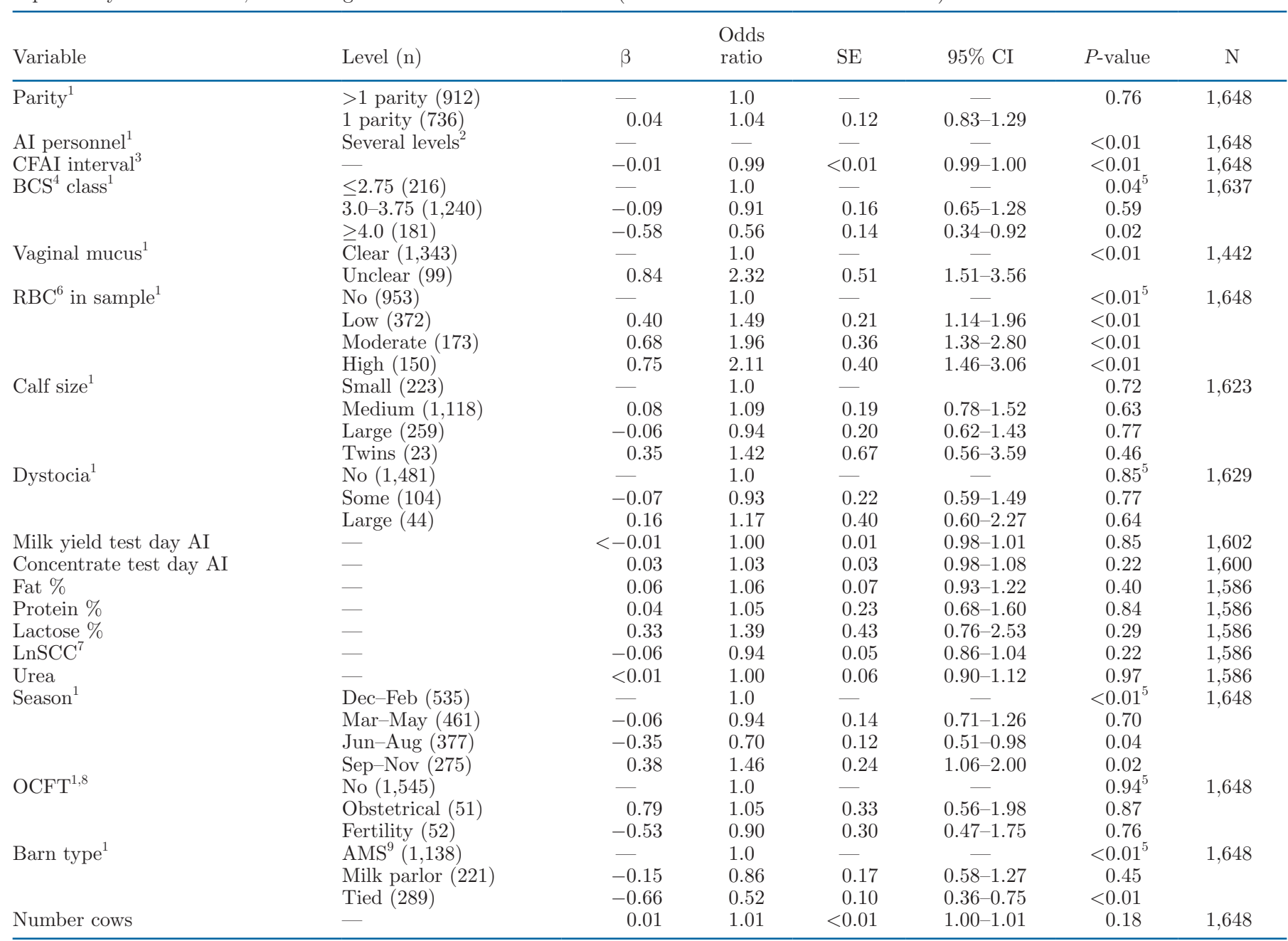

\footnotetext{
${ }^{1}$ Categorical variable.

${ }^{2}$ Levels A-J for AI personnel.

${ }^{3} \mathrm{CFAI}=$ interval from calving to first AI.

${ }^{4} \mathrm{BCS}=$ level $1-5$.

${ }^{5}$ Overall Wald test for categorical explanatory variables.

${ }^{6} \mathrm{RBC}=$ red blood cells.

${ }^{7} \mathrm{LnSCC}=$ natural logarithm somatic cell count.

${ }^{8} \mathrm{OCFT}=$ obstetrical condition or fertility treatment before first AI.

${ }^{9} \mathrm{AMS}=$ automated milking system.
}

for no CYTO increased odds ratio from 1.01 to 1.16 by increasing the interval to first AI by $21 \mathrm{~d}$.

\section{Model 2: Associations Between the Likelihood of Pregnancy to First Al and the Explanatory Variables}

The univariable analyses on relationships between pregnancy after first AI and predictor variables are presented in Table 4. The following variables were associated with pregnancy to first AI: CYTO or the
PMN occurrence as a continuous variable, parity, AI personnel, test day MY, test day CA, barn type, and obstetrical conditions or fertility treatments before first AI.

In the multivariable model presented in Table 5, the pregnancy success after first AI was associated with CYTO, AI personnel, test day MY, barn type, and obstetrical conditions or fertility treatments before first AI. The odds ratio for nonpregnancy increased by a factor of 1.51 for a cow with CYTO compared with a CYTO-negative cow. 
Table 3. Multivariable model describing associations between the occurrence of cytological endometritis $(0=$ no, baseline, 1 = yes) and explanatory variables in 1,439 Norwegian Red cows from 116 herds (herd is included as a random effect in the model)

\begin{tabular}{|c|c|c|c|c|c|c|}
\hline Variable & Level & $\beta$ & $\begin{array}{l}\text { Odds } \\
\text { ratio }\end{array}$ & $\mathrm{SE}$ & $95 \% \mathrm{CI}$ & $P$-value \\
\hline \multirow[t]{10}{*}{$\overline{\mathrm{AI}_{\text {personnel }}{ }^{1}}$} & A & - & 1.0 & - & - & $<0.01^{2}$ \\
\hline & B & -1.54 & 0.21 & 0.07 & $0.12-0.39$ & $<0.01$ \\
\hline & $\mathrm{C}$ & -1.28 & 0.28 & 0.09 & $0.15-0.54$ & $<0.01$ \\
\hline & $\mathrm{D}$ & 0.19 & 1.21 & 0.49 & $0.54-2.67$ & 0.65 \\
\hline & $\mathrm{E}$ & -1.11 & 0.33 & 0.07 & $0.22-0.49$ & $<0.01$ \\
\hline & $\mathrm{F}$ & -0.79 & 0.46 & 0.09 & $0.31-0.68$ & $<0.01$ \\
\hline & G & -0.42 & 0.66 & 0.28 & $0.29-1.50$ & 0.32 \\
\hline & $\mathrm{H}$ & -1.05 & 0.35 & 0.14 & $0.16-0.77$ & 0.01 \\
\hline & I & -0.25 & 0.78 & 0.19 & $0.49-1.25$ & 0.30 \\
\hline & $\mathrm{J}$ & -0.51 & 0.60 & 0.17 & $0.34-1.04$ & 0.07 \\
\hline $\mathrm{CFAI}^{3}$ interval & & -0.01 & 0.99 & $<0.01$ & $0.98-1.00$ & $<0.01$ \\
\hline \multirow[t]{2}{*}{ Vaginal mucus $^{1}$} & Clear & - & 1.0 & - & - & 0.03 \\
\hline & Opaque & 0.50 & 1.65 & 0.38 & $1.05-2.60$ & \\
\hline \multirow[t]{4}{*}{$\mathrm{RBC}^{4}$ in sample ${ }^{1}$} & No & - & 1.0 & - & - & $<0.01^{2}$ \\
\hline & Low & 0.25 & 1.28 & 0.20 & $0.94-1.74$ & 0.11 \\
\hline & Moderate & 0.66 & 1.93 & 0.38 & $1.32-2.83$ & $<0.01$ \\
\hline & High & 0.58 & 1.79 & 0.37 & $1.18-2.70$ & $<0.01$ \\
\hline \multirow[t]{3}{*}{ Barn type $^{1}$} & $\mathrm{AMS}^{5}$ & - & 1.0 & - & - & $0.01^{2}$ \\
\hline & Milk parlor & 0.02 & 1.02 & 0.20 & $0.69-1.50$ & 0.93 \\
\hline & Tied & -0.60 & 0.55 & 0.11 & $0.37-0.81$ & $<0.01$ \\
\hline \multirow[t]{4}{*}{ Season $^{1}$} & Dec-Feb & - & 1.0 & - & - & $0.03^{2}$ \\
\hline & Mar-May & -0.04 & 0.97 & 0.16 & $0.71-1.32$ & 0.83 \\
\hline & Jun-Aug & -0.46 & 0.63 & 0.16 & $0.39-1.02$ & 0.06 \\
\hline & Sep-Nov & 0.30 & 1.35 & 0.24 & $0.96-1.90$ & 0.09 \\
\hline Constant & & $<0.01$ & 1.00 & 0.24 & $0.63-1.60$ & 0.99 \\
\hline
\end{tabular}

${ }^{1}$ Categorical variable.

${ }^{2}$ Overall Wald test for categorical explanatory variables.

${ }^{3} \mathrm{CFAI}=$ interval from calving to first $\mathrm{AI}$.

${ }^{4} \mathrm{RBC}=$ red blood cells

${ }^{5} \mathrm{AMS}=$ automated milking system.

\section{Model 3: Associations Between Late Embryo Loss and Explanatory Variables}

In model 3, late embryo loss was only associated with the variable obstetrical conditions or treatment against fertility disorders before first AI. The odds ratio for late embryo loss was 4.37 (95\% CI: $1.77-10.83, P<0.01$ ) in cows treated against reproductive disorders compared with pregnant cows without treatment, whereas for obstetrical conditions, there were no association with late embryo loss.

\section{DISCUSSION}

The present study demonstrated that Norwegian Red, a breed with high calving rates due to selection for fertility and health over the last 50 years, has a high prevalence of cows with CYTO at first AI. The condition had a significant negative effect on the fertility of the breed. However, pregnancy to first AI was still high, as presented in Table 1. The herds and cows included are highly comparable with the population of Norwegian Red according to management system, herd size, season for AI, and MY (TINE Rådgiving, 2019). Moreover, the present study is the first study of CYTO in Norwegian Red and is the largest field study of CYTO so far described in the literature, including 1,648 cows from 116 farms. Other comparable field studies involved between 383 and 1,044 individuals from 1 to 18 farms, mainly with Holstein breed (Dubuc et al., 2010a; Ribeiro et al., 2013; Pascottini et al., 2017a).

Sampling at AI or directly after AI has been published only in 2 studies (Kaufmann et al., 2009; Pascottini et al., 2017a). Thus, solid evidence for cut-off levels defining CYTO-positive animals at AI still remains to be documented. Both studies counted the proportion of PMN from 300 cells. Kaufmann et al. (2009) defined CYTO positive to include all cows with at least one PMN in the slides, whereas Pascottini et al. (2017a) concluded that optimal cut-off was $1 \%$ with sensitivity and specificity equal to $33.8 \%$ and $88.6 \%$, respectively. The predicative positive and negative value was $89.2 \%$ and $32.4 \%$, respectively, indicating that a CYTO-positive cow is very likely to not become pregnant, but also that a negative sample at AI was not at good indicator for a cow to be pregnant. The constructed ROC curve 
in their study showed an area under curve (AUC) equal to 0.62 . In the present study, the AUC was 0.54 with a sensitivity and specificity equal to $32.4 \%$ and $74.9 \%$, respectively. The positive and negative predicative value was $46.6 \%$ and $62.2 \%$, respectively, indicating that the cut-off has a modest ability to predict a CYTO-positive cow to become nonpregnant. However, the odds ratio of a CYTO-positive nonpregnant cow compared with a CYTO-negative pregnant cow was 1.51 and significant in the model presented in Table 5 . Overall pregnancy to first AI was $59.8 \%$, and $53.4 \%$ in CYTO-positive cows, which is high compared with similar studies (Gilbert et al., 2005; Galvão et al., 2009; Pascottini et al., 2017a) and could explain the modest AUC. Various studies

Table 4. Univariable analyses describing associations between nonpregnancy to first AI $(0=$ pregnant baseline, $1=$ not pregnant $)$ and explanatory variables in 1,449 Norwegian Red cows from 116 herds (herd is included as a random effect)

\begin{tabular}{|c|c|c|c|c|c|c|c|}
\hline Predictor & Level (n) & $\beta$ & $\begin{array}{l}\text { Odds } \\
\text { ratio }\end{array}$ & $\mathrm{SE}$ & $95 \% \mathrm{CI}$ & $P$-value & $\mathrm{N}$ \\
\hline \multirow[t]{2}{*}{ Parity $^{1}$} & $>1$ parity $(790)$ & - & 1.0 & - & - & - & 1,449 \\
\hline & 1 parity $(659)$ & -0.22 & 0.80 & 0.09 & $0.65-1.00$ & 0.05 & \\
\hline AI personnel $^{1}$ & Several levels $^{2}$ & - & - & - & - & $<0.01$ & 1,449 \\
\hline $\mathrm{CFAI}^{3}$ interval & & $<0.01$ & 1.00 & $<0.01$ & $1.00-1.00$ & 0.87 & 1,449 \\
\hline $\mathrm{PMN}^{4}$ continuous & & 0.01 & 1.01 & 0.01 & $1.01-1.02$ & $<0.01$ & 1,449 \\
\hline \multirow{2}{*}{$\mathrm{CYTO}^{1,5}$} & No $(1,043)$ & - & 1.0 & - & - & - & 1,449 \\
\hline & Yes $(406)$ & 0.40 & 1.50 & 0.18 & $1.18-1.91$ & $<0.01$ & \\
\hline \multirow[t]{3}{*}{$\mathrm{BCS}^{1}$} & $2.0-2.75(188)$ & - & 1.0 & - & - & $0.11^{6}$ & 1,439 \\
\hline & $3.0-3.75(1,096)$ & 0.29 & 1.34 & 0.23 & $0.95-1.88$ & 0.09 & \\
\hline & $\geq 4.0(155)$ & 0.03 & 1.03 & 0.25 & $0.64-1.65$ & 0.91 & \\
\hline \multirow[t]{2}{*}{ Vaginal mucus $^{1}$} & Clear $(1,188)$ & - & 1.0 & - & - & - & 1,265 \\
\hline & Opaque $(77)$ & -0.07 & 0.93 & 0.23 & $0.58-1.51$ & 0.78 & \\
\hline \multirow[t]{4}{*}{$\mathrm{RBC}^{7}$ in sample ${ }^{1}$} & No $(839)$ & - & 1.0 & - & - & $0.39^{6}$ & 1,449 \\
\hline & Low $(329)$ & -0.01 & 1.00 & 0.14 & $0.76-1.29$ & 0.94 & \\
\hline & Moderate (152) & 0.29 & 1.33 & 0.25 & $0.93-1.91$ & 0.12 & \\
\hline & High (131) & -0.10 & 0.91 & 0.18 & $0.61-1.34$ & 0.62 & \\
\hline \multirow[t]{4}{*}{ Calf size ${ }^{1}$} & Small (199) & - & 1.0 & - & & $0.56^{6}$ & 1,430 \\
\hline & Medium (989) & 0.16 & 1.17 & 0.19 & $0.84-1.61$ & 0.35 & \\
\hline & Large $(224)$ & 0.24 & 1.27 & 0.26 & $0.85-1.90$ & 0.25 & \\
\hline & Twins (18) & 0.54 & 1.72 & 0.77 & $0.59-4.08$ & 0.28 & \\
\hline \multirow[t]{3}{*}{ Dystocia $^{1}$} & No $(1,307)$ & - & 1.0 & - & - & $0.27^{6}$ & 1,434 \\
\hline & Some $(88)$ & -0.01 & 0.99 & 0.23 & $0.63-1.56$ & 0.98 & \\
\hline & Large (39) & 0.54 & 1.72 & 0.58 & $0.89-3.32$ & 0.11 & \\
\hline Milk yield test day AI & & 0.02 & 1.02 & 0.01 & $1.01-1.04$ & $<0.01$ & 1,406 \\
\hline Concentrate test day AI & & 0.07 & 1.07 & 0.03 & $1.02-1.12$ & $<0.01$ & 1,406 \\
\hline Fat $\%$ & & 0.03 & 1.03 & 0.07 & $0.90-1.17$ & 0.69 & 1,394 \\
\hline Protein $\%$ & & -0.04 & 0.71 & 0.15 & $0.47-1.08$ & 0.11 & 1,394 \\
\hline Lactose $\%$ & & -0.20 & 0.82 & 0.23 & $0.47-1.42$ & 0.47 & 1,394 \\
\hline $\operatorname{LnSCC}^{8}$ & & 0.02 & 1.02 & 0.05 & $0.93-1.11$ & 0.72 & 1,394 \\
\hline \multirow{5}{*}{ Season ${ }^{1}$} & & 0.05 & 1.05 & 0.06 & $0.95-1.16$ & 0.38 & 1,394 \\
\hline & Dec-Feb (464) & - & 1.0 & - & - & $0.28^{6}$ & 1,449 \\
\hline & Mar-May (409) & 0.10 & 1.11 & 0.16 & $0.84-1.46$ & 0.48 & \\
\hline & Jun-Aug (338) & 0.05 & 1.05 & 0.17 & $0.77-1.43$ & 0.77 & \\
\hline & Sep-Nov (238) & -0.23 & 0.80 & 0.14 & $0.57-1.12$ & 0.18 & \\
\hline \multirow[t]{3}{*}{$\mathrm{OCFT}^{1,9}$} & No $(1,360)$ & - & 1.0 & - & - & $0.01^{6}$ & 1,449 \\
\hline & Obstetrical (44) & 0.11 & 1.11 & 0.36 & $0.60-2.08$ & 0.74 & \\
\hline & Fertility (45) & 0.94 & 2.55 & 0.82 & $1.36-4.80$ & $<0.01$ & \\
\hline \multirow[t]{3}{*}{ Milking system ${ }^{1}$} & $\operatorname{AMS}^{10}(1,000)$ & - & 1.0 & - & - & $<0.01^{6}$ & 1,449 \\
\hline & Milk parlor (196) & -0.45 & 0.64 & 0.11 & $0.45-0.90$ & 0.01 & \\
\hline & Tied (253) & 0.58 & 1.78 & 0.26 & $1.34-2.37$ & $<0.01$ & \\
\hline Number cows & & $<-0.01$ & 1.00 & $<0.01$ & $0.99-1.00$ & 0.51 & 1,449 \\
\hline
\end{tabular}

${ }^{1}$ Categorical variable.

${ }^{2}$ Levels A-J for AI personnel.

${ }^{3} \mathrm{CFAI}=$ interval from calving to first $\mathrm{AI}$.

${ }^{4} \mathrm{PMN}=$ polymorphonuclear neutrophils on a continuous scale.

${ }^{5} \mathrm{CYTO}=$ cytological endometritis.

${ }^{6}$ Overall Wald test for categorical explanatory variables.

${ }^{7} \mathrm{RBC}=$ red blood cells.

${ }^{8} \mathrm{LnSCC}=$ natural logarithm somatic cell count.

${ }^{9} \mathrm{OCFT}=$ obstetrical condition or fertility treatment before first AI.

${ }^{10} \mathrm{AMS}=$ automated milking system. 
Table 5. Multivariable model describing associations between nonpregnancy to first AI $(0=$ pregnant baseline, $1=$ not pregnant) and explanatory variables in 1,406 Norwegian Red cows from 116 herds (herd is included as a random effect in the model)

\begin{tabular}{|c|c|c|c|c|c|c|}
\hline Variable & Level & $\beta$ & $\begin{array}{l}\text { Odds } \\
\text { ratio }\end{array}$ & SE & $95 \% \mathrm{CI}$ & $P$ \\
\hline \multirow[t]{2}{*}{$\mathrm{CYTO}^{1,2}$} & No & - & 1.0 & - & - & - \\
\hline & Yes & 0.41 & 1.51 & 0.19 & $1.17-1.94$ & $<0.01$ \\
\hline \multirow[t]{10}{*}{ AI personnel ${ }^{1}$} & $\mathrm{~A}$ & - & 1.0 & - & - & $<0.01^{3}$ \\
\hline & $\mathrm{B}$ & 0.16 & 1.18 & 0.28 & $0.75-1.86$ & 0.48 \\
\hline & $\mathrm{C}$ & 0.38 & 1.46 & 0.36 & $0.90-2.36$ & 0.12 \\
\hline & $\mathrm{D}$ & 0.57 & 1.77 & 0.43 & $1.10-2.86$ & 0.02 \\
\hline & $\mathrm{E}$ & 0.08 & 1.08 & 0.21 & $0.75-1.57$ & 0.67 \\
\hline & $\mathrm{F}$ & -0.12 & 0.89 & 0.16 & $0.63-1.26$ & 0.51 \\
\hline & G & -0.07 & 0.94 & 0.34 & $0.46-1.90$ & 0.85 \\
\hline & $\mathrm{H}$ & -0.08 & 0.93 & 0.28 & $0.51-1.69$ & 0.80 \\
\hline & I & 1.05 & 2.87 & 0.71 & $1.77-4.65$ & $<0.01$ \\
\hline & $\mathrm{J}$ & 0.46 & 1.59 & 0.45 & $0.91-2.76$ & 0.10 \\
\hline Milk yield test day AI & & 0.02 & 1.02 & 0.01 & $1.00-1.03$ & 0.01 \\
\hline \multirow[t]{3}{*}{ Barn type ${ }^{1}$} & $\mathrm{AMS}^{4}$ & - & 1.0 & - & - & $<0.01^{3}$ \\
\hline & Milk parlor & -0.48 & 0.62 & 0.11 & $0.43-0.89$ & 0.01 \\
\hline & Tied & 0.70 & 2.02 & 0.32 & $1.48-2.76$ & $<0.01$ \\
\hline \multirow[t]{3}{*}{$\mathrm{OCFT}^{1,5}$} & No disease & - & 1.0 & - & - & $0.04^{3}$ \\
\hline & Obstetrical & 0.17 & 1.19 & 0.39 & $0.63-2.25$ & 0.60 \\
\hline & Fertility & 0.80 & 2.23 & 0.73 & $1.18-4.22$ & 0.01 \\
\hline Constant & & -1.45 & 0.24 & 0.07 & $0.13-0.41$ & $<0.01$ \\
\hline \multicolumn{7}{|l|}{${ }^{1}$ Categorical variable. } \\
\hline \multicolumn{7}{|c|}{${ }^{2} \mathrm{CYTO}=$ cytological endometritis. } \\
\hline \multicolumn{7}{|c|}{${ }^{3}$ Overall Wald test for categorical explanatory variables. } \\
\hline \multicolumn{7}{|c|}{${ }^{4} \mathrm{AMS}=$ automated milking system. } \\
\hline
\end{tabular}

use ROC curves to establish the cut-off point for the diagnosis of cytological endometritis (Kasimanickam et al., 2004; Dubuc et al., 2010a; Madoz et al., 2013). In the mentioned studies including in this study, the sum of sensitivity and specificity is modest, which can be expected as reproductive success is affected by numerous other factors than the inflammatory status of the uterus (Kasimanickam et al., 2004).

The PMN in the endometrium is a first line of defense against bacterial infections after calving, which should reach its highest occurrence in the first month postpartum, and then a decline (Pascottini and LeBlanc, 2020). Early sampling resulted in a higher cut-off level for the diagnosis of CYTO (Madoz et al., 2013; Arias et al., 2018). Accordingly, we were expecting a low prevalence of CYTO in the present study where the sampling was performed at an average of 72 DIM. However, the prevalence of CYTO in our study population was higher than in other studies sampling at AI or at similar time period after parturition (Kaufmann et al., 2009; Dubuc et al., 2010a; Pascottini et al., 2017a). The average CFAI of $122 \mathrm{~d}$, compared with $72 \mathrm{~d}$ in the present study, partially explains the lower prevalence of CYTO reported by Pascottini et al. (2017a). This assumption is also supported by the trend that a shorter CFAI was a risk factor for the occurrence of CYTO (Pascottini et al., 2017b). Kaufmann et al. (2009) sampled $4 \mathrm{~h}$ after
AI on median 78 DIM using cytobrush and detected at least 1 PMN out of 300 counted cells (i.e., $0.3 \%$ PMN) in $42.8 \%$ of the cows. Dubuc et al. (2010a) sampled on average 56 DIM and diagnosed $13.8 \%$ of cows as CYTO positive, using cytobrush and a cut-off level of $5 \% \mathrm{PMN}$. In the present study, simulating cut-off at $0.3 \%, 1.0 \%$, and $5.0 \%$ PMN, the proportion of CYTO-positive cows would be $58.4 \%, 42.7 \%$, and $20.9 \%$, respectively. In $20.6 \%$ of the samples, 1 to 3 PMN (0.3-1\%) was found. Pascottini et al. (2017a) reported only 3 samples with 1 to $3 \mathrm{PMN}$, whereas $72 \%$ of the samples had no PMN. We suggest that the differences in detection of PMN may be explained by scanning and counting technique.

Pregnancy to first AI in the study population was $59.8 \%$ and comparable to the pregnancy incidence of $61.3 \%$ in Norwegian Red reported by Garmo et al. (2008), supporting the findings by Pascottini et al. (2017a) that pregnancy success is not affected by cytotype sampling of the endometrium at AI. However, Pascottini et al. (2017a) reported an overall conception rate of $43 \%$, which is substantially lower compared with the present study.

In the present study, the odds ratio for nonpregnancy was 1.51 in cows with CYTO, whereas the corresponding odds ratio reported by Pascottini et al. (2017a) was 1.76, although AI was performed much later in their study. However, Kaufmann et al. (2009) found no dif- 
ference in conception rate between animals free from PMN or with medium $(>0-15 \%)$ or high $(>15 \%)$ levels of PMN. Previous studies that reported no correlation between PMN in the endometrium and pregnancy outcome suggest that their results might have been due to one or more of the following contributing factors: a lower bacterial load, a more thorough reproduction management in their study designs, or a more effective immune system in the animals (Plöntzke et al., 2010; Prunner et al., 2014). It is reasonable to believe that breed is an important factor because fertility trait has been included in Norwegian Red breeding program since 1972 (Andersen-Ranberg et al., 2005). Earlier literature suggests that CYTO is a result of a nonoptimal uterine immune function (Cheong et al., 2011; Wagener et al., 2017; Pascottini and LeBlanc, 2020). Although mechanisms for good reproductive performance in Norwegian Red are not fully known, the high pregnancy rate in animals with CYTO, as well as the low incidence of clinical cases of endometritis, may indicate that Norwegian Red has a beneficial uterine immunology.

Opaque vaginal discharge was detected in few cows, and very few $(0.7 \%)$ cows were diagnosed with clinical endometritis according to the definitions by Sheldon et al. (2006). Dubuc et al. (2010a) reported clinical endometritis in $12 \%$ of the cows using Metricheck in Holstein cows. Metricheck has been shown to better detect clinical endometritis than other methods such as vaginoscopy and gloved hand technique (Pleticha et al., 2009). Hence, several studies might have underestimated the condition. Individuals with clinical endometritis have generally been excluded in studies of subclinical endometritis, due to the interference between the definition of the conditions (Kasimanickam et al., 2004; Kaufmann et al., 2009; Plöntzke et al., 2010). In some studies that investigated CYTO (Dubuc et al., 2010a; Pascottini et al., 2017a), the higher prevalence of positive animals might be explained by inclusion of individuals with opaque vaginal discharge. However, because only 10 cows in the present study suffered from endometritis, the results of CYTO were not affected by this condition. This is supported by low number of treatments against metritis and endometritis of 1.3/100 cow-years in the NDHRS (TINE Rådgiving, 2019).

The risk of contaminating the endometrial samples with PMN from the vagina and cervix was reduced by the plastic sheet covering the insemination gun. Opaque mucus in the Metricheck test was associated with CYTO in endometrial samples, but not with pregnancy outcome. Dubuc et al. (2010a) found that only 38\% of the individuals with purulent vaginal discharge diagnosed by Metricheck also suffered from CYTO, when it was diagnosed by cytobrush, which contradicted earlier beliefs that purulent vaginal discharge normally comes from the endometrium. The only other study of risk factors for CYTO at AI used visual registration of the perineum, which was not sufficient to diagnose purulent vaginal discharge or its relation to CYTO (Pascottini et al., 2017b).

Red blood cells in the endometrial samples were associated with CYTO, but not with the pregnancy success after first AI, and hence were not related to postestrus bleeding. The occurrence of RBC could be due to sensitive mucosa, by sampling method, or perhaps a tighter cervix in Norwegian Red compared with Holstein. However, PMN was not necessarily found close to RBC in the slides, rather between epithelial cells in the focus areas. Pascottini et al. (2015) used amount of blood as a slide quality control and did not consider RBC as a risk factor for CYTO (Pascottini et al., 2017b), but suggested it could change the CYTO diagnosis due to low amounts of PMN circulating in blood. However, a comparison between cytotape and cytobrush techniques revealed agreement in PMN occurrence despite increased amount of RBC in cytobrush samples (Pascottini et al., 2015).

Season for AI has been evaluated as a risk factor for CYTO in several studies. For example, Pascottini et al. (2017b) found that heat stress was a risk factor for CYTO at AI, whereas Prunner et al. (2014) found no correlation between season and the occurrence of PMN. The present study found lower risk for CYTO in the summer and spring time compared with winter season. In Norway, the cold summer climate reduces the risk for heat stress compared with warmer countries. Fertility is better in the summer months (Geno SA, 2016), perhaps due to outdoor management and more daylight (Reksen et al., 1999). Nevertheless, pregnancy success was not affected by season in the present study.

Barn type was associated with CYTO, where tiestall herds had less CYTO-positive cows. In contrast, Prunner et al. (2014) reported higher PMN occurrence in tiestalls than calving pens. Regardless of CYTO status, the pregnancy success to first AI was higher for cows in freestall herds, hence not largely affected by the higher incidence of CYTO. These results correlate with earlier evidence of a higher reproductive success in Norwegian Red managed in freestalls (Simensen et al., 2010), as well as a calculation from NDHRS data where the nonreturn rate on d 56 for freestalls and tiestalls was 72.3 $(\mathrm{n}=85,793)$ and $67.8(\mathrm{n}=55,562)$, respectively (Geno Breeding and AI Association, Hamar, Norway, personal communication).

A shorter CFAI interval was a risk factor for CYTO. This finding was supported in one earlier study performed in average 68 DIM (Cheong et al., 2011), whereas another study only found such correlation after 124 DIM (Pascottini et al., 2017b). These data support 
the use of lower cut-offs to diagnose CYTO at AI than what has been used in most studies that sampled at earlier time points. The length of CFAI did not affect pregnancy results in the present study even though the interval was approximately $10 \mathrm{~d}$ shorter than the population average of $82 \mathrm{~d}$ (Geno SA, 2016).

Low or decreasing BCS has previously been shown to contribute to a higher risk for CYTO (Wagener et al., 2017; Valdmann et al., 2018), whereas other studies did not report this association (Cheong et al., 2011; Pascottini et al., 2017b). In the present study, BCS at first AI was not associated with CYTO or pregnancy outcome, which could be explained by few cows with low BCS at AI. In a previous study, loss in BCS from CFAI was related to pregnancy success in Norwegian Red (Gillund et al., 2001). Hence, measurement of BCS loss from parturition to AI would be a more relevant measure. Norwegian Red is a dual-purpose breed selected for both milk and meat, and has a relatively thick muscle layer. The backfat thickness has been measured to be less than half of that measured in Holstein dairy cows at the same BCS score (Gillund et al., 1999). Most of the cows $(75.2 \%)$ in this study were in optimal body condition (3.0-3.75), which may have contributed to a high rate of embryo survival despite the relatively high frequency of CYTO. Earlier literature supports an association between a nonoptimal BCS and poor blastocyst development in vitro (Snijders et al., 2000; Armstrong et al., 2001).

Negative energy balance and systemic inflammation plays an important role in control of uterine immune function and the development of CYTO in Holstein cows (Dubuc et al., 2010b; Cheong et al., 2011; Pascottini and LeBlanc, 2020). Parameters such as nonesterified acids, BHB, or haptoglobin that measure levels of negative energy balance or systemic inflammation have not been published in Norwegian Red.

Our definition of embryo loss did not consider fertilization failure. Fertilization rate is described to be 90 to $100 \%$ for heifers and probably a bit lower and more variable in high-producing dairy cows (Diskin et al., 2016). The study population showed a lower occurrence of embryo loss compared with global estimates (Sreenan et al., 2001). Cows treated for fertility disease before first AI had a much higher risk of losing an embryo (odds ratio $=4.37$ ), whereas obstetric conditions did not affect the outcome. Embryo quality is dependent on the microenvironment of the uterus (Evans and Walsh, 2012; Gilbert, 2012; Leroy et al., 2017), which in turn may be altered by many factors. Medical treatment as such may alter the metabolism of the uterus, or the disease leading to treatment may alter it. Earlier literature describes an association between both insufficient and exaggerated blood progesterone levels preceding
AI, and high embryo mortality rate (Diskin et al., 2016). In this context, Lamming and Darwash (1998) earlier reported that a persistent corpus luteum could alter the progesterone levels and affect embryo survival rate negatively. The association between treatment for fertility disease and late embryo loss found in the present study may not be a result of the treatment itself, but rather connected to the treated disorders that can cause imbalances in the hormone cycle.

Interestingly, CYTO at first AI did not affect late embryo survival, suggesting that late embryo loss is mainly influenced by other factors yet to be investigated. Earlier literature supports that an inflamed environment has a negative effect on embryo quality in vitro (Hill and Gilbert, 2008). However, in one in vivo study of superovulated cows the embryo survival rate was higher in cows whose proportion of PMN had a slight increase from AI to flushing at d 7, compared with those with no PMN at the 2 occasions (Drillich et al., 2012). The present study, together with the previous study of Drillich et al. (2012), indicates that some extent of inflammation, as measured by PMN in the uterine endometrium, may not be of major concern regarding pregnancy outcome.

\section{CONCLUSIONS}

The overall pregnancy incidence to first AI was high and the negative association with CYTO was significant, although its biological effect appears to be modest. The risk for CYTO was associated with CFAI, abnormal mucus condition, RBC, season, AI personnel, and barn type. Risk factors for nonpregnancy to first AI were CYTO, AI personnel, barn type, MY, and obstetrical conditions or fertility treatments before first AI. The occurrence of embryo loss was low compared with global estimates and late embryo loss was not related to CYTO at first AI. Our results suggest that even if Norwegian Red cows show a fairly high prevalence of PMN in uterine cytology, it does not seem to have a major effect on fertility. It appears that the inclusion of fertility in Norwegian red breeding programs for almost 50 years has resulted in improved production traits, with genetically advantageous uterine immunology possibly being one of the mechanisms behind this observation. Further studies are necessary to reveal the genetics behind these traits, a hot topic considering a recent change from progeny testing to genomic selection.

\section{ACKNOWLEDGMENTS}

The authors acknowledge the financial support from The Research Council of Norway (NFR 255097/ E50) and the Norwegian Red cattle breeding company 
Geno. We gratefully thank the AI technicians for their effort and positive spirit in this project, the farmers for their valuable contribution, and Hege Brun Hansen (Norwegian University of Life Sciences, Oslo) for advice in cytological challenges. Support for the preparation of the antiprogesterone monoclonal antibody and the progesterone peroxidase conjugate was provided by the Estonian Research Council (Tartu, Estonia). We thankfully acknowledge Ian Mayer (Norwegian University of Life Sciences, Oslo) for the English language support. The authors have not stated any conflicts of interest.

\section{REFERENCES}

Andersen-Ranberg, I. M., G. Klemetsdal, B. Heringstad, and T. Steine. 2005. Heritabilities, genetic correlations, and genetic change for female fertility and protein yield in Norwegian dairy cattle. J. Dairy Sci. 88:348-355. https://doi.org/10.3168/jds.S0022 -0302(05)72694-1.

Animalia. 2020. Referansekodeverket for husdyrsjukdommer i Norge. Oslo, Norway. In Norwegian. Accessed Aug. 24, 2020. https://www .animalia.no/contentassets/290271c745cf4849a4616193ee21862d/ 01.04.2020---referansekodeverk-for-husdyrsjukdommer-i-norge.pdf.

Arias, L. A. Q., M. V. Fernández, J. J. B. González, M. B. López, P. G. Herradón, and A. I. P. Martínez. 2018. Subclinical endometritis in dairy cattle. Pages 79-97 in New Insights into Theriogenology. IntechOpen.

Armstrong, D. G., T. G. McEvoy, G. Baxter, J. J. Robinson, C. O. Hogg, K. J. Woad, R. Webb, and K. D. Sinclair. 2001. Effect of dietary energy and protein on bovine follicular dynamics and embryo production in vitro: Associations with the ovarian insulinlike growth factor system. Biol. Reprod. 64:1624-1632. https://doi .org/10.1095/biolreprod64.6.1624.

Cheong, S. H., D. V. Nydam, K. N. Galvão, B. M. Crosier, and R. O. Gilbert. 2011. Cow-level and herd-level risk factors for subclinical endometritis in lactating Holstein cows. J. Dairy Sci. 94:762-770. https://doi.org/10.3168/jds.2010-3439.

Diskin, M. G., and D. G. Morris. 2008. Embryonic and early foetal losses in cattle and other ruminants. Reprod. Domest. Anim. 43:260-267. https://doi.org/10.1111/j.1439-0531.2008.01171.x.

Diskin, M. G., S. M. Waters, M. H. Parr, and D. A. Kenny. 2016. Pregnancy losses in cattle: Potential for improvement. Reprod. Fertil. Dev. 28:83-93. https://doi.org/10.1071/RD15366.

Dohoo, I., M. Wayne, and S. Henrik. 2009. Veterinary Epidemiologic Research. 2nd ed. VER Inc.

Drillich, M., D. Tesfaye, F. Rings, K. Schellander, W. Heuwieser, and M. Hoelker. 2012. Effects of polymorphonuclear neutrophile infiltration into the endometrial environment on embryonic development in superovulated cows. Theriogenology 77:570-578. https:// doi.org/10.1016/j.theriogenology.2011.08.033.

Dubuc, J., T. F. Duffield, K. E. Leslie, J. S. Walton, and S. J. LeBlanc. 2010a. Definitions and diagnosis of postpartum endometritis in dairy cows. J. Dairy Sci. 93:5225-5233. https://doi.org/10.3168/ jds.2010-3428.

Dubuc, J., T. F. Duffield, K. E. Leslie, J. S. Walton, and S. J. LeBlanc. 2010b. Risk factors for postpartum uterine diseases in dairy cows. J. Dairy Sci. 93:5764-5771. https://doi.org/10.3168/jds.2010 -3429 .

Edmonson, A. J., I. J. Lean, L. D. Weaver, T. Farver, and G. Webster. 1989. A body condition scoring chart for Holstein dairy cows. J. Dairy Sci. 72:68-78. https://doi.org/10.3168/jds.S0022 -0302(89)79081-0.

Evans, A. C., and S. W. Walsh. 2012. The physiology of multifactorial problems limiting the establishment of pregnancy in dairy cattle. Reprod. Fertil. Dev. 24:233-237. https://doi.org/10.1071/ RD11912.
Galvão, K., L. Greco, J. Vilela, M. Sá Filho, and J. Santos. 2009. Effect of intrauterine infusion of ceftiofur on uterine health and fertility in dairy cows. J. Dairy Sci. 92:1532-1542. https://doi.org/ 10.3168/jds.2008-1615.

Garmo, R. T., A. O. Refsdal, K. Karlberg, E. Ropstad, A. Waldmann, J.-F. Beckers, and O. Reksen. 2008. Pregnancy incidence in Norwegian Red cows using nonreturn to estrus, rectal palpation, pregnancy-associated glycoproteins, and progesterone. J. Dairy Sci. 91:3025-3033. https://doi.org/10.3168/jds.2007-0778.

Geno SA. 2016. Geno Annual statistics report. Accessed Jun. 30, 2020. https://www.geno.no/globalassets/geno-sa/02_dokumenter/06 _om-geno/genos-virksomhet/arsberetning-2016.pdf.

Gilbert, R. O. 2012. The effects of endometritis on the establishment of pregnancy in cattle. Reprod. Fertil. Dev. 24:252-257. https:// doi.org/10.1071/RD11915.

Gilbert, R. O., S. T. Shin, C. L. Guard, H. N. Erb, and M. Frajblat. 2005. Prevalence of endometritis and its effects on reproductive performance of dairy cows. Theriogenology 64:1879-1888. https:// doi.org/10.1016/j.theriogenology.2005.04.022.

Gillund, P., O. Reksen, Y. T. Gröhn, and K. Karlberg. 2001. Body condition related to ketosis and reproductive performance in Norwegian dairy cows. J. Dairy Sci. 84:1390-1396. https://doi.org/10 .3168/jds.S0022-0302(01)70170-1.

Gillund, P., O. Reksen, K. Karlberg, A. Randby, I. Engeland, and B. Lutnæs. 1999. Utprøvning av en holdvurderingsmetode på NRFkyr. Norsk Vet 111:623-632.

Hill, J., and R. Gilbert. 2008. Reduced quality of bovine embryos cultured in media conditioned by exposure to an inflamed endometrium. Aust. Vet. J. 86:312-316. https://doi.org/10.1111/j.1751 $-0813.2008 .00326 . \mathrm{x}$

Kasimanickam, R., T. F. Duffield, R. A. Foster, C. J. Gartley, K. E. Leslie, J. S. Walton, and W. H. Johnson. 2004. Endometrial cytology and ultrasonography for the detection of subclinical endometritis in postpartum dairy cows. Theriogenology 62:9-23. https:// doi.org/10.1016/j.theriogenology.2003.03.001.

Kaufmann, T. B., M. Drillich, B.-A. Tenhagen, D. Forderung, and W. Heuwieser. 2009. Prevalence of bovine subclinical endometritis $4 \mathrm{~h}$ after insemination and its effects on first service conception rate. Theriogenology 71:385-391. https://doi.org/10.1016/j .theriogenology.2008.08.005.

Lamming, G. E., and A. O. Darwash. 1998. The use of milk progesterone profiles to characterise components of subfertility in milked dairy cows. Anim. Reprod. Sci. 52:175-190. https://doi.org/10 .1016/S0378-4320(98)00099-2.

Leroy, J. L. M. R.. J. De Bie, L. Jordaens, K. Desmet, A. Smits, W. F. A. Marei, P. E. J. Bols, and V. Van Hoeck. 2017. Negative energy balance and metabolic stress in relation to oocyte and embryo quality: An update on possible pathways reducing fertility in dairy cows. Anim. Reprod. 14:497-506. https://doi.org/10.21451/1984 -3143-AR992.

Madoz, L. V., M. J. Giuliodori, M. Jaureguiberry, J. Plöntzke, M. Drillich, and R. L. De la Sota. 2013. The relationship between endometrial cytology during estrous cycle and cutoff points for the diagnosis of subclinical endometritis in grazing dairy cows. J. Dairy Sci. 96:4333-4339.

Martin, P., and P. Bateson. 2007. Measuring Behavior: An Introductory Guide. 3rd ed. Cambridge University Press.

Pascottini, O. B., P. Dini, M. Hostens, R. Ducatelle, and G. Opsomer. 2015. A novel cytologic sampling technique to diagnose subclinical endometritis and comparison of staining methods for endometrial cytology samples in dairy cows. Theriogenology 84:1438-1446. https://doi.org/10.1016/j.theriogenology.2015.07.032.

Pascottini, O. B., M. Hostens, P. Dini, M. Van Eetvelde, P. Vercauteren, and G. Opsomer. 2016. Prevalence of cytological endometritis and effect on pregnancy outcomes at the time of insemination in nulliparous dairy heifers. J. Dairy Sci. 99:9051-9056. https://doi .org/10.3168/jds.2016-11348.

Pascottini, O. B., M. Hostens, P. Sys, P. Vercauteren, and G. Opsomer. 2017a. Cytological endometritis at artificial insemination in dairy cows: Prevalence and effect on pregnancy outcome. J. Dairy Sci. 100:588-597. https://doi.org/10.3168/jds.2016-11529. 
Pascottini, O. B., M. Hostens, P. Sys, P. Vercauteren, and G. Opsomer. 2017b. Risk factors associated with cytological endometritis diagnosed at artificial insemination in dairy cows. Theriogenology 92:1-5. https://doi.org/10.1016/j.theriogenology.2017.01.004.

Pascottini, O. B., and S. J. LeBlanc. 2020. Modulation of immune function in the bovine uterus peripartum. Theriogenology 150:193-200. https://doi.org/10.1016/j.theriogenology.2020.01.042.

Pleticha, S., M. Drillich, and W. Heuwieser. 2009. Evaluation of the Metricheck device and the gloved hand for the diagnosis of clinical endometritis in dairy cows. J. Dairy Sci. 92:5429-5435. https://doi .org/10.3168/jds.2009-2117.

Plöntzke, J., L. V. Madoz, R. L. De la Sota, M. Drillich, and W. Heuwieser. 2010. Subclinical endometritis and its impact on reproductive performance in grazing dairy cattle in Argentina. Anim. Reprod. Sci. 122:52-57. https://doi.org/10.1016/j.anireprosci.2010 .07 .006 .

Prunner, I., K. Wagener, H. Pothmann, M. Ehling-Schulz, and M. Drillich. 2014. Risk factors for uterine diseases on small-and medium-sized dairy farms determined by clinical, bacteriological, and cytological examinations. Theriogenology 82:857-865. https://doi .org/10.1016/j.theriogenology.2014.06.015.

Reksen, O., A. Tverdal, K. Landsverk, E. Kommisrud, K. E. Bøe, and E. Ropstad. 1999. Effects of photointensity and photoperiod on milk yield and reproductive performance of Norwegian red cattle. J. Dairy Sci. 82:810-816. https://doi.org/10.3168/jds.S0022 -0302(99) 75300-2.

Ribeiro, E. S., F. S. Lima, L. F. Greco, R. S. Bisinotto, A. P. A. Monteiro, M. Favoreto, H. Ayres, R. S. Marsola, N. Martinez, W. W. Thatcher, and J. E. P. Santos. 2013. Prevalence of periparturient diseases and effects on fertility of seasonally calving grazing dairy cows supplemented with concentrates. J. Dairy Sci. 96:5682-5697. https://doi.org/10.3168/jds.2012-6335.

Sheldon, I. M., and H. Dobson. 2004. Postpartum uterine health in cattle. Anim. Reprod. Sci. 82-83:295-306. https://doi.org/10 .1016/j.anireprosci.2004.04.006.

Sheldon, I. M., G. S. Lewis, S. LeBlanc, and R. O. Gilbert. 2006 Defining postpartum uterine disease in cattle. Theriogenology 65:1516-1530. https://doi.org/10.1016/j.theriogenology.2005.08 .021 .

Sheldon, I. M., and S. E. Owens. 2017. Postpartum uterine infection and endometritis in dairy cattle. Anim. Reprod. 14:622-629. https: //doi.org/10.21451/1984-3143-AR1006.

Simensen, E., O. Østerås, K. E. Bøe, C. Kielland, L. E. Ruud, and G. Næss. 2010. Housing system and herd size interactions in Norwegian dairy herds; associations with performance and disease incidence. Acta Vet. Scand. 52:14.
Snijders, S. E. M., P. Dillon, D. O'Callaghan, and M. P. Boland. 2000. Effect of genetic merit, milk yield, body condition and lactation number on in vitro oocyte development in dairy cows. Theriogenology 53:981-989. https://doi.org/10.1016/S0093-691X(00)00244-2.

Sreenan, J. M., M. G. Diskin, and D. G. Morris. 2001. Embryo survival rate in cattle: A major limitation to the achievement of high fertility. BSAS Occasional Publication 26:93-104. https://doi.org/10 .1017/S0263967X00033619.

TINE Rådgiving. 2019. Annual report: Statistikksamling 2018. Ås, Norway. In Norwegian. Accessed May 18, 2020. https://medlem .tine.no/aktuelt/nyheter/hk-statistikker/_attachment/476965?_ts $=169 \mathrm{bdf} 74 \mathrm{e} 93$.

Valdmann, M., J. Kurykin, T. Kaart, G.-K. Mällo, and A. Waldmann. 2018. Relationships between plasma insulin-like growth factor-1 and insulin concentrations in multiparous dairy cows with cytological endometritis. Vet. Rec. 183:126. https://doi.org/10.1136/ vr.104640.

Wagener, K., C. Gabler, and M. Drillich. 2017. A review of the ongoing discussion about definition, diagnosis and pathomechanism of subclinical endometritis in dairy cows. Theriogenology 94:21-30. https://doi.org/10.1016/j.theriogenology.2017.02.005.

Waldmann, A. 1993. Enzyme immunoassay (EIA) for milk progesterone using a monoclonal antibody. Anim. Reprod. Sci. 34:19-30. https://doi.org/10.1016/0378-4320(93)90046-T.

Waldmann, A. 1999. Monoclonal antibodies to progesterone: Characterization and selection for enzyme immunoassay in bovine milk. Hybridoma 18:289-296. https://doi.org/10.1089/027245799315952.

Williams, E. J., D. P. Fischer, D. U. Pfeiffer, G. C. England, D. E. Noakes, H. Dobson, and I. M. Sheldon. 2005. Clinical evaluation of postpartum vaginal mucus reflects uterine bacterial infection and the immune response in cattle. Theriogenology 63:102-117. https: //doi.org/10.1016/j.theriogenology.2004.03.017.

Zavy, M. T., and R. D. Geisert. 1994. Embryonic Mortality in Domestic Species. CRC Press.

\section{ORCIDS}

S. Diaz-Lundahl ํㅏㄴ https://orcid.org/0000-0002-9099-308X

R. T. Garmo @ https://orcid.org/0000-0002-8222-773X

T. B. Klem (1) https://orcid.org/0000-0001-5138-775X

A. Waldmann () https://orcid.org/0000-0002-6903-9638

A. K. Krogenæs (ํ) https://orcid.org/0000-0001-6280-5697

\section{APPENDIX}

Table A1. Number of cows with endometrial samples, BCS, milk yield, concentrate allocation, mucus evaluation, milk content samples, progesterone samples, and pregnancy diagnosis

\begin{tabular}{lc}
\hline Item & Number of cows \\
\hline Endometrial samples & 1,648 \\
BCS & 1,637 \\
Mucus evaluation & 1,442 \\
Milk yield recorded & 1,602 \\
Concentrate recorded & 1,600 \\
Test day milk content; protein, fat, lactose, urea, and SCC & 1,586 \\
Progesterone first AI & 1,488 \\
Progesterone 21 d after first AI & 1,287 \\
Progesterone at first AI and 21 d & 1,287 \\
Pregnancy controls, manual rectal palpation, or pregnancy-associated & 1,449 \\
glycoprotein analysis & \\
\hline
\end{tabular}

